\title{
Implementation of indonesian teacher learning processes and digital literation for teachers in junior high school
}

\author{
Ahmad Basori $^{1}$, Dessy Wardiah $^{2}$, Yessi Fitriani ${ }^{2}$ \\ ${ }^{1}$ Sekolah Menengah Pertama Negeri 13 OK, Baturaja, Indonesia \\ ${ }^{2}$ Universitas PGRI Palembang, Indonesia
}

\begin{tabular}{l} 
Article Info \\
\hline Article history: \\
Received Jul $12^{\text {th }}, 2021$ \\
Revised Aug $16^{\text {th }}, 2021$ \\
Accepted Aug $30^{\text {th }}, 2021$ \\
\hline Keyword: \\
Implementation \\
Indonesian language teacher \\
Covid-19 pandemic
\end{tabular}

Covid-19 pandemic

\begin{abstract}
This is to determine the effect of work motivation and principal leadership together on the performance of teachers in SD Negeri Lengkiti District. In this study, quantitative research methods were used and the research design was in the form of an influence study, namely to determine the effect of the three variables, namely the independent or independent variable Teacher Motivation (X1), Principal Leadership (X2) and the dependent or dependent variable Teacher Performance $(\mathrm{Y})$. The results of the study can be concluded as follows: 1) The variable of work motivation of the SD Negeri Lengkiti District teachers is in the sufficient category, 2) The leadership variable of the principal of SD Negeri Lengkiti District is in the good category, 3) The work motivation of the teacher and the leadership of the principal is factors that can improve teacher performance.
\end{abstract}

C 2021 The Authors. Published by IICET.

This is an open access article under the CC BY-NC-SA license (https://creativecommons.org/licenses/by-nc-sa/4.0

\section{Corresponding Author:}

Basori, A.,

Sekolah Menengah Pertama Negeri 13 OK, Baturaja, Indonesia

Email: abasori1968@gmail.com

\section{Introduction}

The Indonesian language learning process at SMP Negeri 13 OKU has been carried out as well as other existing schools, both in Ogan Komering Ulu Regency and in South Sumatra Province and even in Indonesia. In the learning process delivered by the teacher based on learning tools that have been compiled and planned.

The implementation of the Indonesian language learning process and even other subjects is divided into 2 (two) stages, namely learning given to students in odd semesters and even semesters. However, since the outbreak called the COVID-19 pandemic, starting in April, the learning process has been carried out at home (BDR) by utilizing technology facilities via cellphones using the zoom application or the WhattsApp application, so that the learning process delivered continues as usual even without face to face.

As conveyed at the Online National Seminar (Webinar) on May 21, 2020 which was held at FKIP, PGRI Palembang University, [1] with the title of the role of character education in learning Indonesian during the Covid 19 pandemic, it was stated that during the Covid pandemic 19 all learning activities have to be carried out online or online learning. There are those who use the WhatsApp group application, zoom cloud meeting, google classroom or others so that the teaching and learning process can be carried out. This is because in the midst of the corona virus pandemic, all members of the community must stay at home, work from home, and maintain a distance (social / physical distancing) so that they are not infected with the virus. 
Based on the news quoted from Media Indonesia on March 23, 2020 with the topic of learning during the pandemic, Syamsir Alam, the Curriculum Development and Assessment Division explained that the Covid-19 pandemic has created the need and need to maintain distance in social interaction (social distancing), quarantine and isolation so that each individual vulnerable will not be affected by virus. Efforts are made one with purose that the health care system is not overwhelmed battery bat increasing number of clients to be served.

Society should understand benefit of clicking seek sloping curve (flattening the curve), an approach that is used to prevent and / or stop the speed deploymen covid-19. This model clicking hen climb that every individual can undertake responsibility / parts to slow the spread of the virus. The desire to realize flattening the curve into sa was one of the main reasons Kebijakan government to ask the students to learn from home (BDR), so that their opportunity to be able to come together in the form of the crowd can be prevented, and therefore the chance propagation covid-19 can be inhibited [2]

In connection with the Indonesian language learning process in the Covid 19 pandemic situation, so that the learning process continues, an understanding is needed for teachers so that the learning components to be delivered continue as usual by utilizing technological tools including cellphones, laptops (Notebooks) .

Lack of preparation of teachers and school management as well as minimum deliberation that cause limited time per preparation is given, cause policy study from home (BDR) took criticism / complaints from some people. Most public complained of BDR, as a classroom activity to move activities from school to home with a load / task even more. In addition, some schools also continue to carry out assessment activities for the benefit of grade promotion report cards for lower grades. The students in the final grade are still overshadowed by the graduation exam / UNBK. It seems that the final examination / UNBK will only be postponed and not stopped. Students are faced with multiple anxiety; covid-19 plague of the 19th and tasks / se final exam school graduation / UNBK. BDR approach that can now lead the students (and possibly teachers), lost oportunity understanding and me understand the deeper events that are facing society and nation today. They're going to lose the important moments to reflect in order to foster social solidarity, caring, empathy, and the opportunity to think about the contribution that can be given to help the community in these difficult times.

In this emergency situation, packing charge learners an BDR, should be loaded with the strengthening of literacy and character. Content is taught, se other to develop students' knowledge (rote learning), also used as a medium to foster and strengthen the literacy skills and character. As an estab activity study formal, assessor 's remains to be done. However, ratings do not BDR to determine standar attainment ( Attainment level) or interest value ( assigning grade ) alone.

So, the covid-19 pandemic does not change the system that was planned. It can even carry out an online MidSemester Result Assessment (IPM) starting April 1 to April 8 2020. The BDR policy can be said to be more beneficial for the assessment carried out. Because students can work independently, not being influenced by other friends, so that the learning outcomes are truly pure. After the BDR policy was extended until April 14, 2020, of course the teacher had to re-interact with students in online classroom learning. However, teachers do not need to worry because in this emergency, President Jokowi has also conveyed the existence of free online learning assistance from a number of online education services such as the Teacher Room, Zenius, Google Suite for Education, and so on. For this, it is the parents who must provide assistance. Learning Indonesian in this emergency period, the implementation of the Indonesian language learning process and digital literacy for teachers of SMP Negeri 13 OKU in East Baturaja District in a covid 19 pandemic situation may be easier to apply.

Based on the implementation of the learning process for teachers at SMP Negeri 13 OKU, East Baturaja District, especially Indonesian language learning has followed the rules set by the Government, even though initially the teacher experienced a few obstacles due to a process like this that had just been implemented and the delay of an appeal from the Government recommending that learning be implemented with online system .

The principal at SMP Negeri 13 Oku, East Baturaja District explained that online learning patterns must be part of all learning even if only as a complement. The point is that teachers get used to teaching online . The sudden implementation of the online learning system made most educators surprised. In the future, there must be a system change policy for the implementation of online learning that is even more effective. Teachers must have implemented technology-based learning through digital literacy according to the capacity and availability of technology.

The ministry's initiative to prepare the Rumah Belajar online learning portal deserves to be supported even though online affairs during Covid 19 which forced students and teachers to carry out activities at home still needed support from online service providers from the Government, because currently existing schools in each region, especially SMP Negeri 13 OKU, East Baturaja District has not been able to provide a base of learning services by utilizing technology such as having internet network facilities ( Wifi Hotspot ). Teachers with their own funds use 
the internet quota available on communication tools, so that the implementation of the learning process, especially Indonesian, can run well.

Based on the description of the background of the problem above, the researcher wants to find out more about learning Indonesian in a COVID-19 pandemic situation through a research entitled, " Implementation of Indonesian Language Learning Process and Digital Literacy for Teachers of SMP Negeri 13 OKU in East Baturaja District in a Covid-Pandemic Situation. 19. "

\section{Method}

This research method is a qualitative descriptive method. Qualitative methods are used to analyze data in the form of information on how to implement the Indonesian language learning process and digital literacy for teachers of SMP Negeri 13 OKU in East Baturaja District in a covid-19 pandemic situation.

\section{Results and Discussions}

Based on the research results, the results of the implementation of the learning process for Indonesian language teachers and digital literacy for teachers of SMP Negeri 13 OKU in East Baturaja District are as follows.

1. The implementation of the learning process for Indonesian language teachers and digital literacy for teachers of SMP Negeri 13 OKU in East Baturaja District in the covid-19 pandemic situation was carried out through an online system using online and offline. The learning process uses mobile media through the WhatsApp application and the Zoom application .

2. Obstacles that hinder the implementation of the Indonesian language learning process and digital literacy for teachers of SMP Negeri 13 OKU in East Baturaja District in the COVID-19 pandemic situation, including the limited time for Indonesian language teachers to carry out the learning process, including frequent disruption of signals and student activity in following lessons with the Online system . Not all students have a communication device in the form of a cellphone, so an alternative is sought, namely by asking these students to join other students whose homes are close together.

The implementation of the Indonesian language learning process and even other subjects is divided into 2 (two) stages, namely learning given to students in odd semesters and even semesters. However, since the outbreak called the COVID-19 pandemic, starting in April, the learning process was carried out at home (BDR) by utilizing technology facilities via cellphones using the Zoom application or the WhattsApp application, so that the learning process that is delivered continues as usual even without face to face.

Lack of preparation of teachers and school management as well as minimum deliberation that disebabkan limited time per preparation is given, cause policy study from home (BDR) took criticism / complaints from some people. Most ma syarakat complained of BDR, as a classroom activity to move activities from school to home with a load / task even more. In addition, some schools also continue to carry out assessment activities for the benefit of grade promotion report cards for lower grades. The students in the final grade are still overshadowed by the graduation exam / UNBK. It seems that the final examination / UNBK will only be postponed and not stopped. Students are faced with multiple anxiety; covid plague of the 19th and tasks / se final exam school graduation / UNBK. BDR approach that can now lead the students (and possibly teachers), lost oportunity understanding and me understand the deeper events that are facing society and nation today. They're going to lose the important moments to reflect in order to foster social solidarity, caring, empathy, and the opportunity to think about the contribution that can be given to help the community in these difficult times.

The ministry's initiative to prepare the Rumah Belajar online learning portal deserves to be supported even though online affairs during Covid 19 which forced students and teachers to carry out activities at home still needed support from online service providers from the Government, because currently existing schools in each region, especially SMP Negeri 13 OKU, East Baturaja District has not been able to provide a base of learning services by utilizing technology such as having internet network facilities ( Wifi Hotspot ). Teachers with their own funds use the internet quota available on communication tools, so that the implementation of the learning process, especially Indonesian, can run well.

Content is taught, se other to develop students' knowledge ( rote learning ), also used as a medium to foster and strengthen the literacy skills and character. As an estab activity study formal, assessor 's remains to be done. However, ratings do not BDR to determine stan dar attainment ( Attainment level) or interest value ( assigning grade ) alone. Assessment in the BDR is done properly with the aim of helping students to find a way to defend jar 
better for themselves her on every subject studied / taught. Such an assessment is called formative assessment, namely the score / value of an activity evaluation not a standard pen performance and or purpose proceess learning. Because if we use it as the goal of the learning process, the real value which is a measure of the learning status will be lost and it will distort the expected learning process .

As conveyed at the Online National Seminar (Webinar) on May 21, 2020 which was held at FKIP, PGRI Palembang University, [1] with the title of the role of character education in learning Indonesian during the Covid 19 pandemic, it was stated that during the Covid pandemic 19 all learning activities have to be carried out online or online learning. There are those who use the WhatsApp group application, zoom cloud meeting, google classroom or others so that the teaching and learning process can be carried out. This is because in the midst of the corona virus pandemic, all members of the community must stay at home, work from home, and maintain a distance (social / physical distancing) so that they are not infected with the virus. This research strengthens current research studies, where Wardarita's research touches on the implementation of learning during the Covid-19 pandemic.

The next research tracing is research conducted [3] through his article entitled, "Learning Indonesian Language in the Middle of the Covid 19 Pandemic." Tasropi explained that the government implements learning through online and offline systems so that the learning process can still be carried out, considering that the current pandemic condition is considered very worried about the safety of students and teachers themselves as teachers.

Further research investigations, namely research conducted [4] with the title, " Online Learning Amid the Covid19 Outbreak." The results of this study explain that the Covid-19 Pademi has disrupted the conventional learning process. So a solution is needed to answer these problems. Online learning is an alternative that can solve this problem. The research objective was to obtain an overview of the implementation of online learning in the Biology Education Study Program, FKIP Jambi University as an effort to reduce the spread of covid-19 in tertiary institutions. The research subjects were students of the Biology Education Study Program. Data were collected by interview via zoom cloud meeting. Data analysis was performed using the interactive analysis technique of Miles \& Huberman. The results showed that: (1) students already have the basic facilities needed to take part in online learning; (2) online learning has flexibility in its implementation and is able to encourage independent learning and motivation to be more active in learning; and (3) distance learning encourages the emergence of social distancing behavior and minimizes the appearance of student crowds so that it is considered to reduce the potential for the spread of Covid-19 in tertiary institutions. Weak supervision of students, lack of strong signals in remote areas, and high quota fees are challenges in online learning. Increasing independent learning, interest and motivation, courage to express ideas and questions are other advantages of online learning. This research strengthens current research studies, where Sadikin's research examines the learning process during the Covid 19 pandemic.

[5] "The Role of Information and Communication Technology Literacy in Distance Learning during the Covid19 Pandemic." The results of this study conclude that the Covid-19 pandemic has provided significant changes in various sectors, including the education sector. Distance learning (PJJ) is a form of adjustment in the education sector during the Covid-19 pandemic. In the implementation of distance learning, technology is the key to the continuation of PJJ which can be a link between teachers and learners who are blocked by distance. However, the existence of technology will not be utilized if it is not accompanied by technology literate technology users. Information and communication technology literacy includes all knowledge and skills in utilizing technology, starting from recognizing the device, operating it, processing and communicating information. Technology and ICT Literacy have an important role in smoothing PJJ, making PJJ more effective, facilitating communication and collaboration between teachers and learners, and encouraging the use of positive technology that promotes responsible social ethics. This research strengthens current research studies, where Latif's research examines the learning process during the Covid 19 pandemic.

\section{Conclusions}

Based on the research results it can be concluded as follows: 1) The implementation of the learning process for Indonesian language teachers and digital literacy for teachers of SMP Negeri 13 OKU in East Baturaja District in the covid-19 pandemic situation is carried out through an online system using online and offline. The learning process uses mobile media through the WhatsApp application and the Zoom application. 2) Obstacles that hinder the implementation of the Indonesian language learning process and digital literacy for teachers of SMP Negeri 13 OKU in East Baturaja District in the COVID-19 pandemic situation, including the limited time for Indonesian language teachers to carry out the learning process, including frequent disruption of signals and student activity in following learning with an online system. Not all students have a communication device in the form of a cellphone, so an alternative is sought, namely by asking these students to join other students whose homes are close together. 


\section{References}

[1] Wardarita, Ratu. 2020. Artikel. Peran Pendidikan Karakter dalam Pembelajaran Bahasa Indonesia Pada Masa Pandemi Covid 19. Seminar Nasional Online (Webinar). Dosen/Guru Besar pada PPS Universitas PGRI.

[2] Abidin. 2015. Artikel. Pendekatan yang Digunakan Untuk Menghambat dan Menghentikan Lajunya Deploymen Covid-19. Jakarta: Media Indonesia.

[3] Tasropi. 2020. Pembelajaran Bahasa Indonesia di Tengah Pandemi Covid 19. Artikel. Media Indonesia.

[4] Sadikin, Ali. 2020. Pembelajaran Daring di Tengah Wabah Covid-19. Jurnal Pendidikan Biologi, Volume 6, Nomor 2, Juli 2020. Halaman: 214-224.

[5] Latip, Abdul. 2020. Peran Literasi Teknologi Informasi dan Komunikasi Pada Pembelajaran Jarak Jauh di Masa Pandemi Covid-19. Jurnal Edukasi dan Teknologi Pembelajaran, Volume 1 Nomor 2, Juni 2020. Halaman: $107-$ 115.

[6] Firmansyah, "Pendidikan Karakter Religiusmelaluiaktivitas Keagamaan Pada Masa Pandemicovid-19di Smp Muhammadiyah 2 Malang.” Universitas Muhammadiyah Malang, 2021.

[7] Rimadhani, "Pendidikan Karakter Sebagai Inovasi Pembelajaran Pada Masa Pandemi Di Sd Se Kecamatan Borobudur," In Prosiding Seminar Nasional Manajemen Pendidikan, 2021, Vol. 2, No. 1.

[8] Utami, "Pelaksanaan Pembelajaran Daring Mata Pelajaran Pai Pada Masa Pandemi Covid-19 Di Smpn 2 Pariangan Kabupaten Tanah Datar Provinsi Sumatera Barat," 2021.

[9] Jannah K. Umam, "Peran Orang Tua Dalam Pendidikan Karakter Berbasis Keluarga Di Masa Pandemi Covid19,” Falasifa J. Stud. Keislam., Vol. 12, No. 1, Pp. 95-115, 2021.

[10] Adha, H. Parikesit, D. R. Perdana, A. T. Hartino, And E. P. Ulpa, "Pendidikan Karakter Melalui Pembelajaran Pkn Di Masa Pandemi Covid-19 Demi Masyarakat Taat Psbb,” 2021. 